\title{
裖㾫(じょく㫕う)予防を目的とした体圧分散マットの開発*
}

\author{
則 次 俊 郎*1, 井 形 俊 也*2 \\ 高岩昌 弘*1, 佐々木大輔*1
}

\section{Development of Medical Care Mat for Prevention of Bedsore}

\author{
Toshiro NORITSUGU*3, Toshiya IGATA, \\ Masahiro TAKAIWA and Daisuke SASAKI \\ ${ }^{* 3}$ Faculty of Engineering, Okayama University, \\ 3-1-1 Tsushimanaka, Okayama-shi, Okayama, 700-8530 Japan
}

\begin{abstract}
According with the advancement of aged society, the further improvement in function of the welfare apparatus for an aged person is required. Although various medical equipments, such as a mat to prevent bedsore begin to be used commercially, the function of prevention of bedsore seems not enough. Moreover, it is require for such a nursing equipment to have the flexibility and safety since it contacts with human directly. In the highly advanced aged society, the nursing people is also aged one and it is necessary to decrease their physical burden. In this study, we have developed a mat which has a function to prevent bedsore. In order to distribute the pressure applied to the body, we have proposed a body pressure distribution strategy by using 24 mats driven independently. And the effectiveness of the proposed method is confirmed through some experiments. In this paper, first of all, the structure of the proposed medical care mat is shown. After-wards, its effectiveness is confirmed through experiments.
\end{abstract}

Key Words: Medical Care Mat, Bedsore, Pneumatics, Body Pressure Distribution

\section{1. はじめに}

現在わが国では少子・高齢化がほかに例を見ない速 さで進行しており, その結果, 介護者不足や高齢者が 高齢者を看護する老々介護が問題となっている． 65 歳以上の要介護者を介護する介護者の半数が 60 歳以 上で女性が多数を占める(1). 褯瘡予防を目的とした電 動ベッドやエアマットなどのさまざまな医療用具の研 究(2)(3) が行われているが, 褯艙予防の確実性はまだ保 証されていない. そのため, 介護者は要介護者が同一 部位に連続した圧迫を受けないように定期的に体位変 換を行ったり，体圧を分散させて圧力を軽減しなけれ ばならない。このような褯瘡予防法は大半の医療・福 祉の現場で行われているが, 2 時間ごとに行う必要が あるため介護者の負担は大きい。そのため介護者の肉 体的, 精神的負担の軽減が重要課題である.

裖瘡予防や治療にはウレタンフォームやエアマット レス等の体圧分散寝具が用いられている，その中でも 空気圧を用いるエアマットは褯瘡予防に有効である(4)

* 原稿受付 2004 年 7 月 12 日.

*1 正員, 岡山大学工学部 ( 700-8530 岡山市津島中 3-1-1).

*2 岡山大学工学部.

E-mail : toshiro@sys.okayama-u.ac.jp
という観点から，体圧分散寝具にはエアマットが多く 用いられている．現在市販されているエアマットには 寝返り機能, パターン圧力加圧機能などがあるが, こ れらは電動ベッドと組合わせて使用しないと, 㯟上げ や起き上がり動作などを行うことができない.そのた めエアマットは裷瘡予防に有効ではあるが, 一日中寝 たきりで生活する要介護者のさまざまな動作の補助を 行うことは不可能である。

そこで本研究では, 褯瘡予防だけでなく要介護者の さまざまな動作の補助ができるような空気圧アクチュ エータを用いた体圧分散マットの開発を行う．空気圧 アクチュエータは, 出力/重量比が高く, 軽量化が容易 である。さらに, 空気の圧縮性による柔軟性は医療や 福祉の分野における対人作業で不可欠な安全性の確保 のために有効である(5).

本研究で提案する体圧分散マットは, ポリエチレン シートからなる 24 個の基本ユニットで構成される. 体圧分散マット内に空気を供給することでマットの高 さを変化させるものであり, 裖瘡予防に有効なさまざ まな動作が可能である. また, 基本ユニットはそれぞ れ独立した動作が可能であるため, 要介護者の動作の 補助も行うことができる. 本論文では, まず, 体圧分 散マットの構造, 動作原理, 基本特性を説明する. 次 
に,いくつかの実験に基づいて, 提案する体圧分散マ ットの有効性を示す.

\section{2. 体圧分散マット}

体圧分散マットの概観を図 1 に示す。体圧分散マッ トは，図 2 に示すような軟質ポリエチレンシートを蛇 腹状の袋にした基本ユニットから構成される。眓 3 の ように人が臥床できる市販のエアマットの大きさ $1800 \times 800 \mathrm{~mm}$ に基づいて，それを頭部，肩部，脇腹 部, 腰部, 下腿部, 踵部の 6 部位に分割し, さらに右半 身，左半身をおのおの二つにした。このように，縦に 6 , 横に 4 , 計 24 ユニット配置し，24 個の制御弁を用 いてそれぞれ独立した動作を行う。これにより，体圧 分散マット上に卧床している要介護者の体圧分散およ び体位変換を行う。ここで, 体圧分散マットの全長が 身長に対して大きすぎる，あるいは小さすぎると， 6 部位に分割した身体部位がそれに対応する基本ユニッ 卜上になく, マットの機能が損なわれるため, はん用 性を有するためには，体圧分散マットの全長は身長と 近い寸法にすることが望ましい. 図 4 に示す約
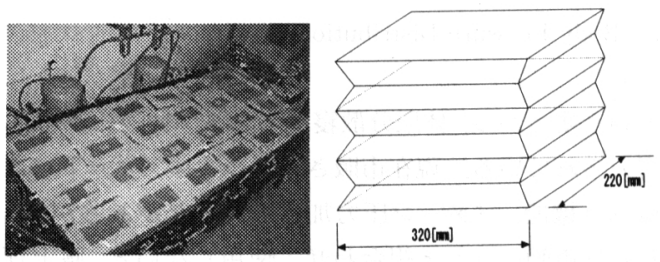

Fig. 1 Medical care mat Fig. 2 Fundamental unit

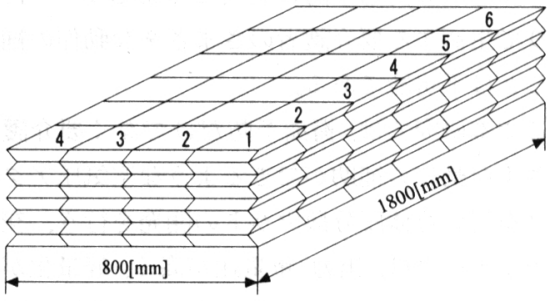

Fig. 3 Medical care mat
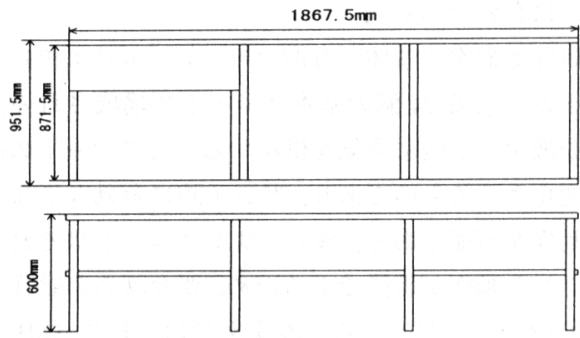

Fig. 4 Frame of distribution medical care mat
$1870 \times 950 \times 600 \mathrm{~mm}$ の台上に体压分散マットを配置 した.

$2 \cdot 1$ 基本ユニットの構造 図 5 に基本ユニット の構造を示す. 厚さ $0.3 \mathrm{~mm}$ の軟質ポリエチレンシ ートを使用し, 上面シート 1 枚, 中間シート 6 枚, 下 面シート 1 枚を熱で溶着し, 空気給排気用のチューブ を取付け，蛇腹状の袋にしたものである．図 5 中で示 す点線は熱で溶着する部分である。なお，マットの素 材をシリコーンゴムシートとした場合, 加圧時に，そ の伸縮性によりマット辺方向へも膨張するため高さ方 向へ十分な変位量が得られない. 軟質ポリエチレンシ ートはシリコーンゴムシートと比較して曲げ剛性は同 程度であるが引張剛性が高いため, 空気を加圧時に効 率良く高さ方向の変位が得られる. 後述のように本マ ットの駆動圧力は数 $\mathrm{kPa}$ と低圧であり, 破裂の心配 はない, また，本マットの材質は市販の介護用エアマ ットなどと同様に耐久性や衛生面などについて別途考 慮する必要がある.今回の実験の範囲内では座屈は生 じなかった。

図 6 に基本ユニットの初期状態抢よび空気加圧時の 概観を示す。図 6 のようにマットが高さ方向へ膨張す ることで，身体に接触する基本ユニットの数が増加し て, 接触面積が大きくなり圧迫部位での除圧ができ る.

$2 \cdot 2$ 基本ユニットの特性の測定 図 7 に加圧力 に対する基本ユニットの高さと発生力の関係を示す.
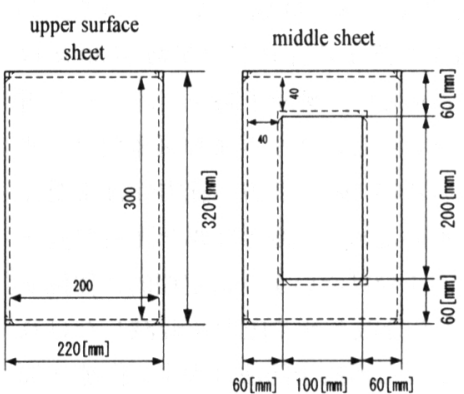

under surface

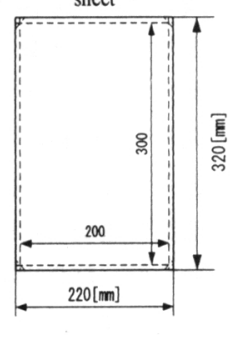

Fig. 5 Structure of mat

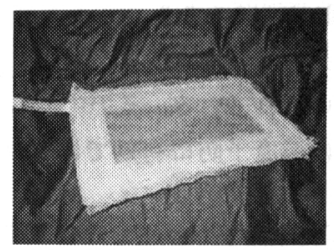

(a) Initial state

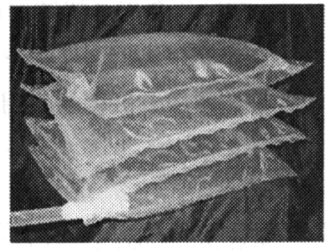

(b) Pressurized state
Fig. 6 Expansion of mat 
基本ユニットとカセンサを両側から板ではさみ，マッ ト内に空気を加圧したときの発生力を測定した。基本 ユニットの高さ $x$ を $20 \sim 200 \mathrm{~mm}$ の $20 \mathrm{~mm}$ 間隔で固 定し, マット内に $1 \sim 8 \mathrm{kPa}$ を $1 \mathrm{kPa}$ 間隔で加圧し た．基本ュニットは, 低圧により大きな発生力と膨張 量を得られることが確認できる。そのため，マット使 用時に高圧エアコンプレッサが不要であり, 病院など で使用の場合は各病室へのガス供給設備, 自宅で使用 の場合はブロアなどが使用でき, 空気圧駆動源の確保 が容易である。

\section{3. 実験装置の概 要}

図 8 に実験装置を示す．各基本ユニットはサーボ弁 (FESTO 社製空気圧サーボバルブ MPYE-5-1/8 $\mathrm{HF} 010 \mathrm{~B})$ に接続されており,コンピュータ (NEC 社 製 PC-9821 V 20 M 7)内で 0〜4 095 の整数として演 算された制御入力值 $u$ は $\mathrm{D} / \mathrm{A}$ 変換器 [INTER$\mathrm{FACE}$ 社製 $98 \mathrm{AD} / \mathrm{DA}$ (12) AZI-3502, 量子化数 12 bit]，[CONTEC 社製 DA 12-4(98)］を介して弁へ出 力される. 各基本ュニットの内圧は, アンプ内蔵型圧 カセンサ (COPAL 社製 PA-500 352 G) により検出さ れる.この検出信号は, A/D 変換器 [INTERFACE

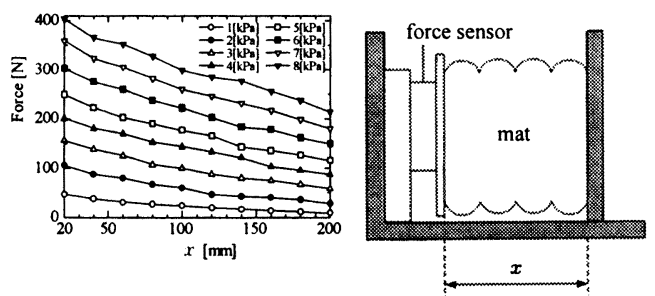

(a) Relation between dis- (b) Measurement method placement and genera. tion force

Fig. 7 Measurement of fundamental characteristic

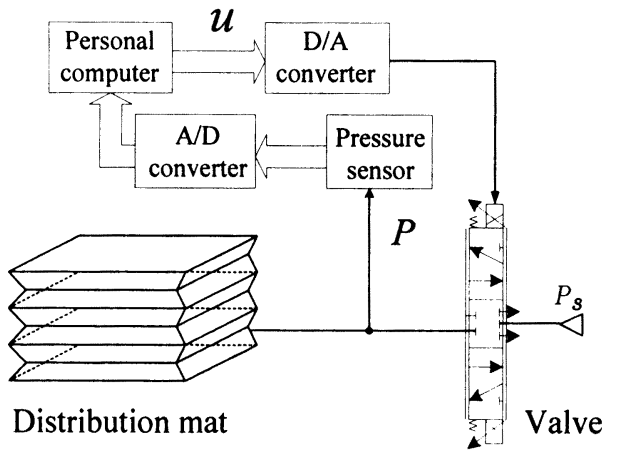

Fig. 8 Control system
社製 $98 \mathrm{AD} / \mathrm{DA}(12) \mathrm{AZI}-3502$ ，量子化数 $12 \mathrm{bit}$, [INTERFACE 社製 $98 \mathrm{AD}$ (12)AZI-272, 量子化数 12 bit）を介してコンピュータ内に取り込まれる。な お, 圧力センサの出力は, ノイズ対策として折れ点周 波数 $3.18 \mathrm{~Hz}$ のローパスフィルタを通している. 供 給圧力 $P_{S}$ は $50 \mathrm{kPa}$ である。

\section{4. 体圧分散動作の有効性}

裖瘡は身体の同一部位への連続した圧迫により発生 するとされている，本研究では，これを防ぐため体圧 分散マットの各ユニットと身体との接触力をソフト触 覚センサシート(6) で検出し, これに基づいて力制御系 を構成する. 力制御により裖瘡予防に有効な接触力を 実現する体圧分散動作を行う。実験ではすべての体圧 分散マットに一定内圧を加圧した場合と, 体圧分散マ ットの各ユニットと身体との接触力を力制御を用いて 調整する場合について体圧分散動作を行う。被験者の 体重は $60 \mathrm{~kg}$ である。

$4 \cdot 1$ ソフト触覚センサシート ソフト触覚セン サシートは, 図 9 に示す円筒状シリコーンゴムを 4 行 4 列に配置し, 上下からシリコーンゴムシートで密封 し, 圧力センサを取付けたものである。図 10 のよう に, 円筒状シリコーンゴム上部には厚さ $2 \mathrm{~mm}$ のシリ

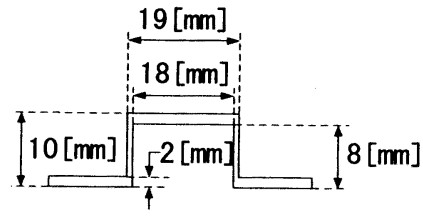

Fig. 9 Cylindrical silicone rubber

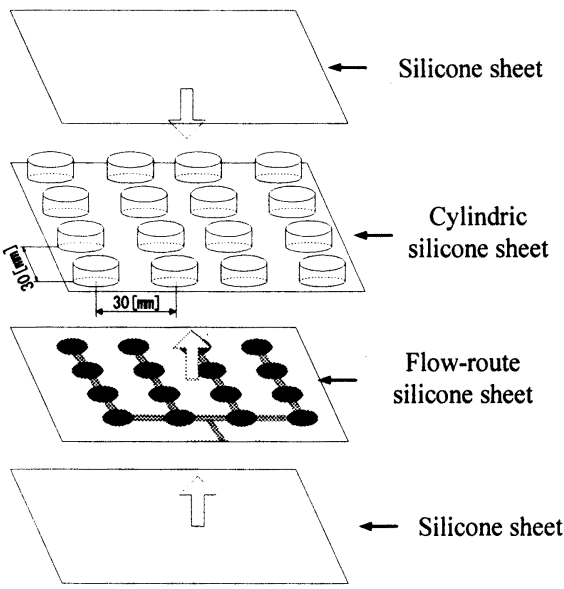

Fig. 10 Structure of tactile sensor sheet 
コーンシートを貼り付け, 下部には厚さ $2 \mathrm{~mm}$ の空気 流路用シリコーンシートとシリコーンシートを貼り付 けている，16個の円筒状シリコーンゴムはおのおの 流路用シリコーンシートにより導通している. 図 11 にソフト触覚センサシートの概観を示す. 図 12 に示 すように, ソフト触覚センサシートに外力が加わると, 円筒状シリコーンゴム内の体積が減少し内圧が上昇す る。その外力と内圧の関係を導出することにより，七 ンサ表面にかかる接触力を検出できる.

ここで，ソフト触覚センサシートに力センサを用い て力を印加した場合, 力センサの值と図 12 ( a ) よりソ フト触覚センサシートの内圧から力に変換された計算 值との関係を図 13 に示す．接触力が小さい場合は多 少の測定誤差はあるが，それ以外では力センサの值と 計算值は本実験に必要な範囲内ではほぼ等しい。これ より,ソフト触覚センサシートを接触力の測定に用い ることは可能である。

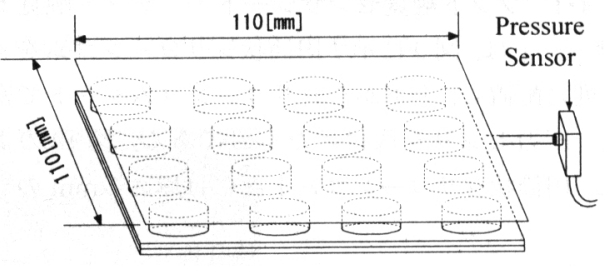

Fig. 11 Tactile sensor sheet

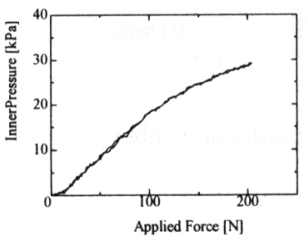

(a) Relation between force and pressure

Fig. 12 Measurement of basic characteristic

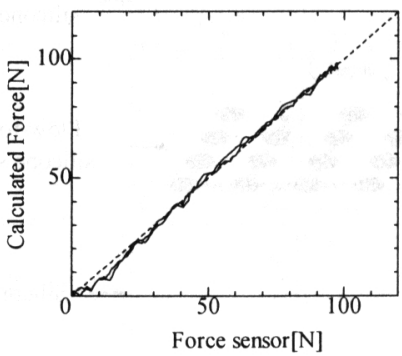

Fig. 13 characteristic of tactile sensor sheet
$4 \cdot 2$ 実験の概要 力制御を用いて各ユニットと 身体の接触力を一定にする体圧分散動作を行う。実験 のようすを図 14 亿示す．体圧分散マットに加わる体 圧は身体の左右ではほぼ等しいと考元られるので, 右 半身の肩, 脇, 腰部の体圧分散マットと身体の間に, ソフト触覚センサシート $(110 \times 110 \mathrm{~mm})$ を設置し, 接 触力を測定する。図 15 亿力制御系を示す.アクチュ エータは体圧分散マットとソフト触覚センサの両方を 示し, $F_{r}$ は目標接触力, $F$ はりフト触覚センサの出 力, $P_{r}$ は体圧分散マットの目標圧力, $P$ は圧力センサ の出力, $C_{1}, C_{2}$ は PI 制御器, $u$ は制御入力である.

一般に身体の毛細血管に $32 \mathrm{mmHg}$ 以上の圧力が加 わると裖瘔が発生するとされている。つまりソフト触 覚センサシート $(110 \times 110 \mathrm{~mm})$ に約 $50 \mathrm{~N}$ 以上の力が 加わると䙏瘡が発生することになる，被験者が仰臥し た状態で, 右半身の肩, 脇, 腰部と体圧分散マットの 接触力の平均が $45 \mathrm{~N}$ であったので, 目標接触力を縓 瘕が発生する $50 \mathrm{~N}$ 以下の $45 \mathrm{~N}$ とする。

肩, 脇, 腰部の体圧分散マットと身体の接触力が目 標接触力 $\left(F_{r}=45 \mathrm{~N}\right)$ となるよう力制御する、ソフト 触覚センサシートを配置していない左半身の体圧分散 マットの目標圧力は, それぞれ対応する右半身の体圧 分散マットの目標圧力と同一とする. 力制御を行う前 にすべての体圧分散マットを一定圧力 $(2 \mathrm{kPa})$ で加圧 し, 全身をある程度持ち上げてから肩, 脇, 腰部を力 制御に切換える。頭, ふくらはぎ, かかと部は一定圧

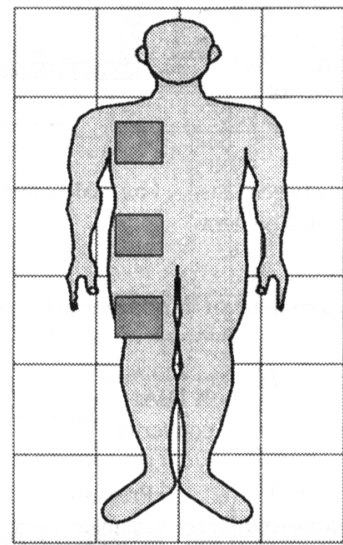

Fig. 14 Arrangement of sensors

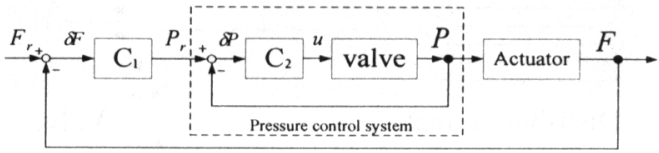

Fig. 15 Force control system 
力 $(2 \mathrm{kPa})$ で加圧する。また，す心゙ての体圧分散マッ トを一定圧力で加圧する方式の体圧分散動作では, 加 圧力は $2 \mathrm{kPa}$ とする.

$4 \cdot 3$ 実験結果および考察体圧分散マットを駆 動した場合の接触力を比較するために, 図 16（a）に体 圧分散マットの内圧が $0 \mathrm{kPa}$ の場合の肩, 脇, 腰部の. 接触力を示す.また, 図 16 ( b ) に体圧分散マットを一 定圧力 $(2 \mathrm{kPa})$ で加圧した場合の肩, 脇, 腰部の接触 力を示し, 図 16(c)に力制御を用いて体圧分散マット と身体の接触力を一定にする体圧分散動作を行った場 合の肩, 脇, 腰部の接触力を示す. 図中の $50 \mathrm{~N}$ の直 線は裖瘡予防に必要な許容接触力である.

脇, 腰部の接触力は体圧分散マットを一定圧力 (2 $\mathrm{kPa}$ )で加圧した場合と力制御を行った場合の両方で

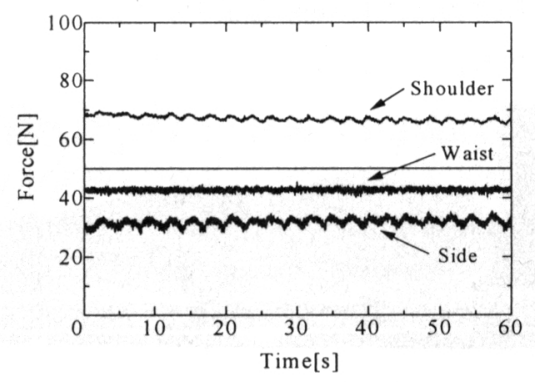

(a) Initial state

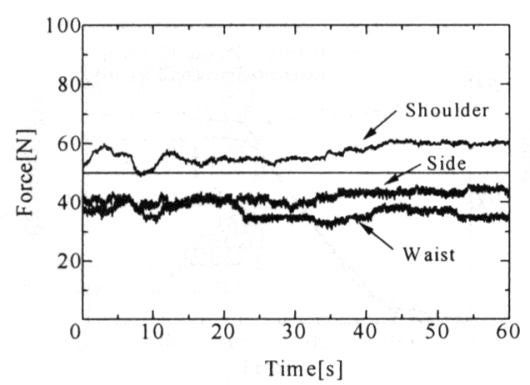

(b) Pressure control system

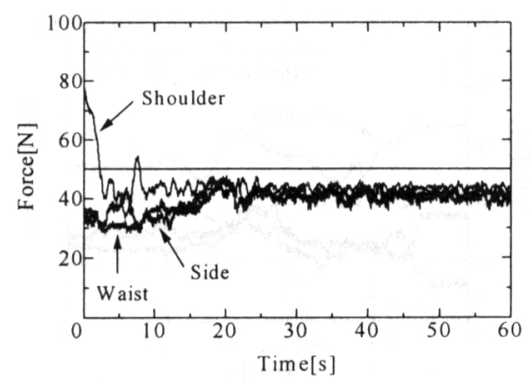

(c) Force control system

Fig. 16 Contact force between body and mat
許容接触力 $(50 \mathrm{~N})$ 以下である。しかし, 肩部の接触力 は体圧分散マットに一定圧力 $(2 \mathrm{kPa})$ で加压した場合

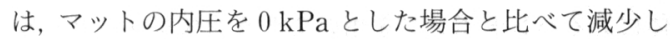
ているが, $50 \mathrm{~N}$ よりも大きくなっている。これに対 して, 力制御を行うことにより, 肩部においても体圧 分散マットと身体の接触力は $50 \mathrm{~N}$ 以下になる。これ より力制御を用いた体圧分散動作を行うことですべて の部位で許容接触力以下になり裖瘡予防に有効である と考えられる。

また図 16(b)で接触力が時間に対して変動してい るのは, 圧力制御によってマット内圧を一定にしてい るが, 体の一部が少し動いてその部位の接触力が変化 すると, 圧力制御系が働いてマットの高さが変化する ため, マット上の被験者に対する接触力の分布も変化 するためである.

$4 \cdot 4$ 局所部の接触圧力測定 裖瘡の発生しやす い局所部の接触圧力を測定する。体圧分散マットの内 圧が $0 \mathrm{kPa}$ の場合, 一定内圧 $(2 \mathrm{kPa})$ を加圧した場合, 力制御を用いた体圧分散動作の場合で，裤瘡の発生し やすい肩甲骨, 仙骨部(図 17)の接触圧力を図 18 に示 す簡易体圧測定器 [帝国藏器製薬(株)製, RB 体圧計] を用いて測定し，体圧分散マットの有効性を検証す

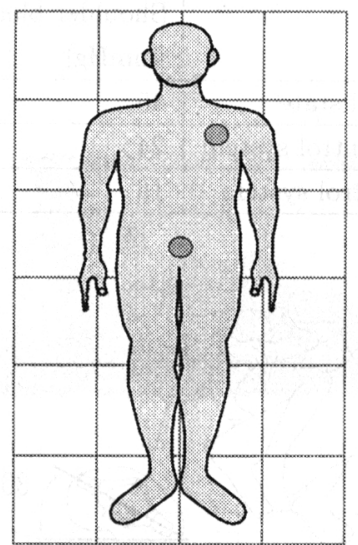

Fig. 17 Arrangement of sensors

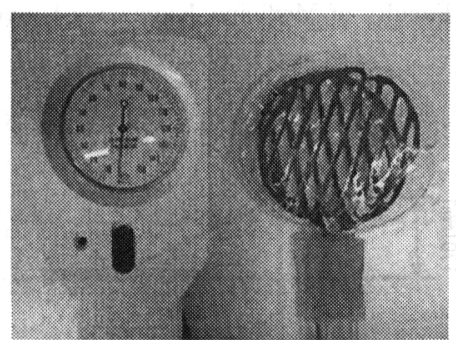

Fig. 18 Body pressure measuring equipment 
る。体圧測定器は身体とマットの間に図 18 右に示す トランスジューサパッドを配置し，左に示す体圧計本 体にあるハンドポンプを用いてトランスジューサパッ ドに空気を加圧し，そのときの体圧ゲージょり接触圧 力を測定するものである．測定可能な最小接触圧力は $10 \mathrm{mmHg}$, 最大接触圧力は $150 \mathrm{mmHg}$ である。測定 はそれぞれ各 3 回測定し，その平均を表 1 に示す.

表 1 に示すようにマットに一定圧力 $(2 \mathrm{kPa})$ で加圧 した場合, 力制御を用いた体圧分散動作の場合両方で 肩甲骨，仙骨部の接触圧力が褛瘡予防に効果的な接触 圧力 (32 mm Hg) 以下になることが確認できる。また 力制御を用いた体圧分散動作の場合はよりいっそうの 接触圧力の減少が得られた。これより力制御を用いた 体圧分散動作を行うことにより䙏瘡予防に効果的な体 圧分散動作が可能である。

\section{5. $30^{\circ}$ 側臥位の実現}

褯瘡予防法として図 19 に示す $30^{\circ}$ 側臥位が有効で あるといわれている. $30^{\circ}$ 側臥位は身体を傾けること により，身体を骨突起のない慰部で支えることによつ

Table 1 Contact force between body and mat

\begin{tabular}{|c|l|c|}
\hline & $\begin{array}{l}\text { Shoulder blade } \\
{[\mathrm{mmHg}]}\end{array}$ & $\begin{array}{c}\text { Scurum } \\
{[\mathrm{mmHg}]}\end{array}$ \\
\hline Initial state & 45 & 50 \\
\hline Pressure control system & 24 & $<10$ \\
\hline Force control system & 16 & $<10$ \\
\hline
\end{tabular}

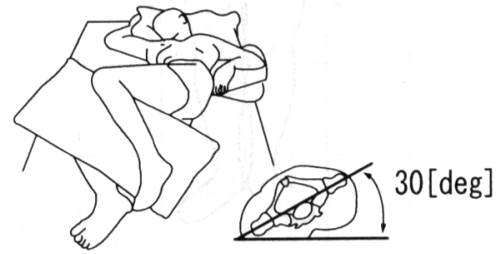

Fig. 19 Change of body attitude

(from Faculty of Medicine, Kanazawa University)

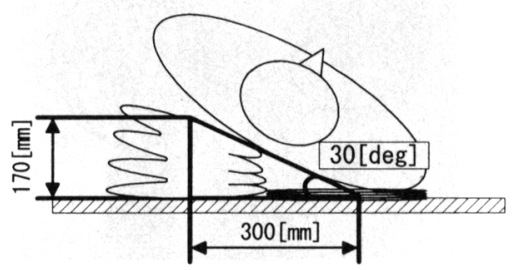

Fig. 20 Change of body height
て接触面積を広げ, 褯痓発生を抑制している。しかし $30^{\circ}$ 側臥位は 2 時間ごとに行う必要があるため介護者 の肉体的負担が大きい. 本研究では体圧分散マットを 用いて $30^{\circ}$ 側臥位を行い, その有効性を調べる.

$30^{\circ}$ 側臥位を実現するためには，図 20 に示すように 体圧分散マットは人間を載せた状態で半身が高さ方向 に $170 \mathrm{~mm}$ 上昇する必要がある。実際に $30^{\circ}$ 側臥位を 行っているようすを図 21 に示す. 実験では半身の体 圧分散マットを駆動させた場合の肩, 腰部の高さ方向 の変位量 $h[\mathrm{~mm}]$ および, そのときの肩, 脇, 腰部の体 圧分散マットと身体の接触力を測定した．高さ方向の 変位量の測定には, CCD カメラとそれによって得ら れた画像を処理する装置(応用計測研究所製 Quick MAG System III 2 D for Windows Color)を用いた. 体圧分散マットの加圧力は図 7 に基づき, 体圧分散マ ットが高さ方向に $170 \mathrm{~mm}$ 膨張するように, 右肩部の

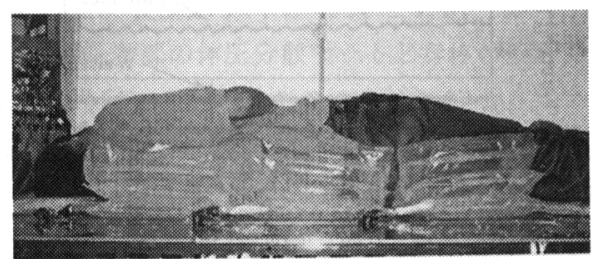

Fig. 21 Change of body attitude

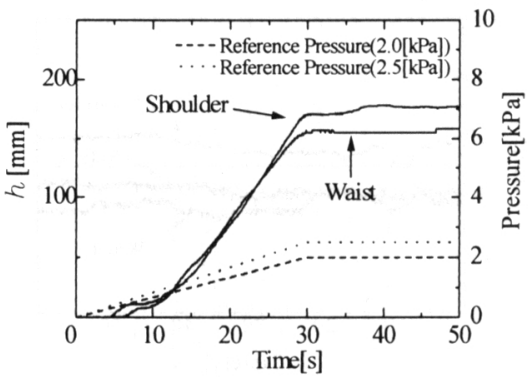

(a) Change of body height

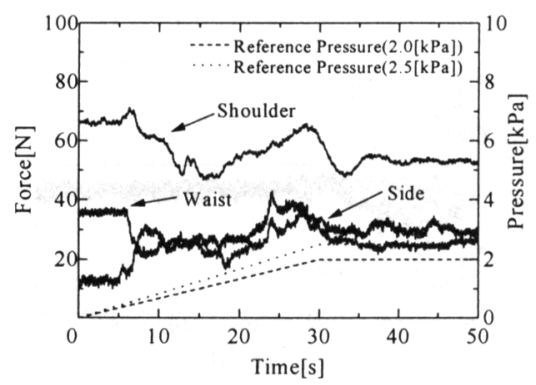

(b) Contact force between body and mat

Fig. 22 Change of body attitude 
体圧分散マットの目標圧力を $2.5 \mathrm{kPa}$ ，それ以外の右 半身部位を $2 \mathrm{kPa}$ とし, 左半身の内压は $0 \mathrm{kPa} と し$ た.内圧は目標圧力までランプ状に印加し, $30 \mathrm{~s}$ 以降 は一定圧力とする. 図 22 に肩, 腰部の高さ方向の変 位量を示し, そのときの肩, 脇, 腰部の体圧分散マッ トと身体の接触力を示す.

実験より, 肩, 腰部においてそれぞれ $30^{\circ}$ 側臥位に 必要な変位量 $170 \mathrm{~mm}$ が得られている. また体圧分 散マットを駆動させることにより, 肩部では接触圧力 の減少が確認できる。

図 22 において体圧分散マット内圧の増加に対し, 身体上昇が約 $5 \mathrm{~s}$ ほど遅れているのは, 体圧分散マッ

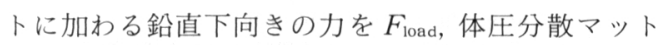
内圧による鉛直上向きの力を $F_{\text {mat }}$ としたとき, $t=0$ 〜 s では $F_{\text {load }}>F_{\text {mat }}$ となり体圧分散マットが膨張し ないためである。

\section{6. 体圧分散マットを用いた产の他の動作}

現在市販されているエアマットは寝返り, パターン 加圧などの機能がある.しかし電動ベッドと組合わせ て使用しないと起き上がり動作などが行えず, 膝上げ やその他の動作も行うことができない. そこで本研究 では, 体圧分散マットのみで起き上がり動作を行う. 動作の決定は, 使用者の意思を反映できるよう簡単な スイッチを用いて行う。体圧分散マットにより起き上
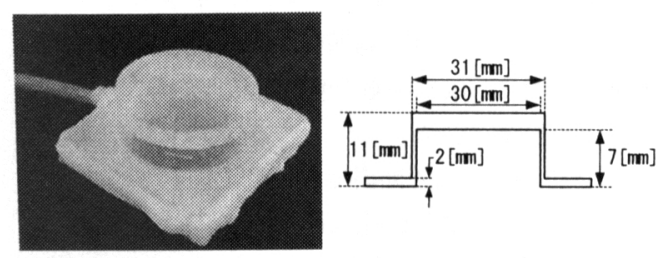

Fig. 23 Structure of tacticle soft sensor

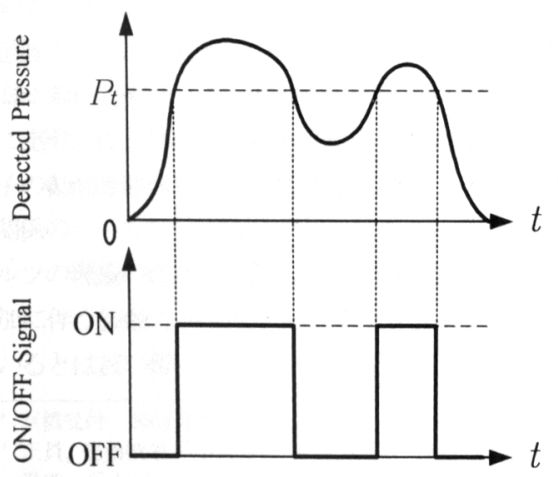

Fig. 24 Detected pressure and $\mathrm{ON} / \mathrm{OFF}$ signal
がり動作の補助を行うことで介護者の肉体的負担を軽 減させるだけでなく, 要介護者の手元にスイッチがあ ることで要介護者の意思を反映させた起き上がり動作 が可能となる.

図 23 に開発したスイッチを示す。ソフト触覚セン サを密閉し内圧を圧力センサを用いて測定するもので ある、スイッチを押すことで図 24 のように上昇した 圧力がしきい值 $P_{t}$ を超えることにより装置の ON/ OFF を切換える。ここでは手でソフト触覚センサを 押し ON/OFF の決定を行うが，手足が不自由な人が 使用する場合にはソフト触覚センサの代わりにチュー ブを用いて呼気を圧力センサで計測ししきい值 $P_{t}$ を 超えることにより装置の $\mathrm{ON} / \mathrm{OFF}$ を切換えることも 可能である.

これより体圧分散マットの目標圧力を上昇させる Up スイッチ, 減少させるDown スイッチを製作し た。ここで開発した Up/Downスイッチを用いて起 き上がり動作を行う。Up/Down スイッチを使用し， 肩, 脇部を加圧, 減圧し体圧分散マットの高さを変化 させることで起き上がり動作を行う.Up スイッチが ON の状態のときは目標圧力が上昇し上半身を起き上 がらせる. 目標圧力は安全のために最大圧力 $P_{\max }(=$ $4 \mathrm{kPa}$ ) 以下である. 脇部の目標圧力は肩部の半分と し, 肩, 脇部両方のマットで身体を支える。実際に起 き上がりを行っているようすを図 25 に示す。マット

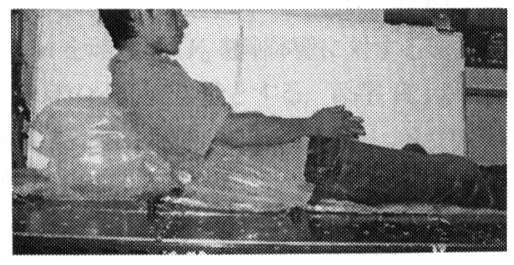

Fig. 25 Change of body height

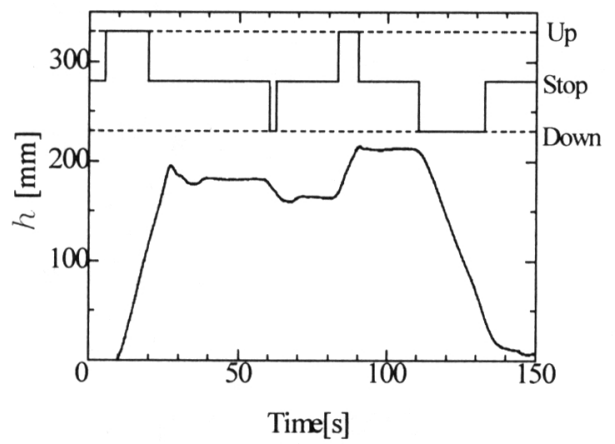

Fig. 26 Change of body height controled with Up/ Down switch 
を駆動させた場合の肩部の高さ方向の変位量 $h[\mathrm{~mm}]$ およびそのときの Up/Down スイッチの状態を図 26 に示す. Up スイッチが ON の状態ではマットが膨張 して身体が上昇しており, Up/Down スイッチが OFF の状態では身体は一定の高さを保っている. Down ス イッチが ON の状態では身体が下降する.Up/Down スイッチを用いることで操作者の意思を反映させた起 き上がり動作が可能となる.

\section{7. おわりに}

本研究では, 褛瘡予防を目的とした体圧分散マット の開発を行った。体圧分散マットの構造と動作原理, 基本特性について記述した後, 実験により体圧分散動 作の有効性を調べた。これにより,下記の結果を得 た.

（1）力制御を用いることにより，体圧分散マット と身体の接触力は裖瘡予防に効果的とされている許容 接触力 $(50 \mathrm{~N})$ 以下になることが確認できた。 また，簡 易体圧測定器を用いて褛瘡が発生しやすい局所部の接 触圧力を測定した結果, 褿瘡予防に効果的とされてい る許容接触圧力 $(32 \mathrm{mmHg})$ 以下になることが確認で
き，体圧分散マットの有効性が示された。

（2）体圧分散マットを用いることで $30^{\circ}$ 側臥位を 行うのに必要な高さ方向の変位が得られるとともに, 接触力が大きい部位での接触力の減少が確認できた。

(3) Up/Down スイッチを用いて起き上がり動作 を行い, 操作者の意思を反映させた起き上がり動作が 可能であることが確認できた.

\section{文献}

（1）平成 15 年厚生労㗢白書, (2003).

(2) Tanimoto, Y., Takechi, H., Nagahata, H. and Yamamoto, H., Pressure Measurement of Air Cushions for SCI Patients, IEEE Trans. Instrument. Mea. surement, 49-3 (2003), 666-670.

（3）谷本義雄・六名泰彦・徳弘昭博・山本秀樹，裤そう予防 における圧力分散効果の定量化, 第 46 回自動制御連合講 演会論文集, (2003)，1222-1225.

(4) 井筒岳・ほか, 体位変換式エアマットと䇾たきり老人の 袮瘡, クリニカルエンジニアリング, 8-8 (1997), 674-680.

（5）則次俊郎, 空気圧アクチュエータ, 日本ロボット学会誌, 15-3 (1997), 355-359.

（6）佐々木大輔・則次俊郎・高岩昌弘, 生活支援ロボットの ための圧力検出型ソフト触覚センサの開発, 機論, 70-689, C (2004), 77-82. 